\section{Military Technical College Kobry El-Kobbah, Cairo, Egypt}

14th International Conference on Applied Mechanics and Mechanical Engineering.

\title{
Microstructural Evolution of porous biomorphous WC and SiC Ceramics
}

\author{
By \\ M. Awaad* \\ S. H. Kenawy* \\ M. A. El-Kherbawi* \\ S. M. Naga*
}

\begin{abstract}
:
A novel way of synthesizing pure WC as well as SiC powders by in situ carbo-thermal reaction of sugar cane and tungstic acid or $\mathrm{Si}$ is presented. Tungsten and silicon carbide bodies were sintered at $1450^{\circ} \mathrm{C}$ under vacuum. The preparation process, catalytic activity, microstructure, and phase composition of the prepared bodies were investigated and characterized. The resultant $\mathrm{WC}$ and $\mathrm{SiC}$ architecture showed a homogeneous finegrained microstructure and good distribution of closed pores. The WC bodies exhibit high activity for dehydrogenation of cyclohexane to cyclohexene with selectivity of $96 \%$ at $200^{\circ}$ to $350^{\circ} \mathrm{C}$.
\end{abstract}

\section{Keywords:}

Composites, Biogenic, Microstructure, WC

\footnotetext{
* Ceramics department, National Research Centre, 12622 Dokki, Cairo, Egypt
} 
** Department of Chemistry, Faculty of Women for Science, Ain Shams University, Asmaa Fahmi st., Cairo, Egypt

\section{Introduction:}

Tungsten carbide (WC) is like other transition metal carbides has unique chemical and physical properties, such as good wear resistance ${ }^{(1,2)}$, chemical stability and high melting point, which make carbide ceramics useful for filter medium, fuel cell electrodes ${ }^{(3)}$, catalysts ${ }^{(4)}$, impact absorbing structure ${ }^{(5)}$ and refractories ${ }^{(6)}$.

Principal application for carbides is as the major constituent in "cemented carbide" cutting tools. But the demand for WC in cutting tool industries is decreasing; its application in the field of catalysis industries is very promising. It substitutes $\mathrm{Pt}, \mathrm{Pd}$ and $\mathrm{Ir}$ in catalysis industries ${ }^{(7,8)}$. In general, it has been shown that metal carbides often possess catalytic advantage over their parent metals in activity, selectivity and resistance to poisoning ${ }^{(9-11)}$. They are demonstrated to have excellent catalytic activities in hydrogenation and dehydrogenation reactions of saturated and unsaturated hydrocarbons

The most common crystal shape of WC in hardmaterials is the truncated trigonal prism, which is considered to be the equilibrium shape of WC grains ${ }^{(6)}$. During the solution / reprecipitation sintering process of WC, grain growth and formation of low - energy prismatic interfaces are produced. Such prismatic grains (truncated trigonal prisms) contain sharp edges. Sharp edges lead to tensile stress concentrations on loading, which promote crack initiation and propagation. On the other hand, rounded WC grains result in a tougher material ${ }^{(7)}$. Rounded WC grains do not form via solution/reprecipitation process during sintering due to energy reasons. They can be obtained by proper powder manufacturing techniques. Herber et al ${ }^{(8)}$ demonstrated that hard materials with distinct rounded WC grains can be obtained by conventional liquid phase sintering.

Conventionally, a number of processes have reported for the synthesis of WC powders. they are produced by heating a mixture of W powder and carbon black. This method is based on diffusion controlled solid state reaction controlled by diffusion and phase transformation. However, high temperatures $\left(1400-1600^{\circ} \mathrm{C}\right)$ and long times $(6-8 \mathrm{~h})$ are necessary ${ }^{(15,16)}$. For this process, the reactions between $\mathrm{C}$ and $\mathrm{W}$ metal depend on the trype of furnace, atmosphere and carbon content as shown by Eqs. (1) and (2) ${ }^{(4)}$.

$$
\begin{aligned}
& 2 \mathrm{~W}+\mathrm{C}=\mathrm{W}_{2} \mathrm{C} \quad \longrightarrow \quad \longrightarrow \text { [1] } \\
& \mathrm{W}+\mathrm{C}=\mathrm{WC}
\end{aligned}
$$

The carburization of metallic tungsten by carbonaceous gasses occurs at a relatively low temperature. Carburization with $\mathrm{CH}_{4}-\mathrm{H}_{2}$ mixture yielded $\mathrm{WC}$ at a temperature as low as $800^{\circ} \mathrm{C}^{(17,18)}$, and complete carburization of $\mathrm{W}$ occurred at higher temperatures ${ }^{(4)}$. This process resulted in deposition of undesirable amounts of free carbon, and the formation of $\mathrm{W}_{2} \mathrm{C}$, along with the synthesis of $\mathrm{WC}$.

WC can be produced by carbo-thermal reduction of tungstic acid with an excess of carbon at $1400^{\circ} \mathrm{C}{ }^{(4)}$. Powders produced by this method have undesirable in homogeneities due to diffusion gradients established during the reduction reaction ${ }^{(19)}$. Koc \& Kodambaka ${ }^{(20)}$ used a carbothermal reduction of carbon coated precursors to produce WC powders. They stated that this method maximizes the reaction rate between the reactants by providing a better distribution of carbon within $\mathrm{WO}_{3}$. Swift et al ${ }^{(21)}$ and Koc \& Kodambaka(4) demonstrated the superiority of carbon coated tungsten oxide precursors. They showed that the formation of WC single phase by carbothermal reduction proceeds through reduction of $\mathrm{WO}_{3}$ to $\mathrm{W}$ via the formation of lower oxides of tungsten, followed by carburization into WC. WC is directly formed without forming $\mathrm{W}_{2} \mathrm{C}$.

On the other hand, synthesis of $\mathrm{SiC}$ structures by mimicking the cellular tissue anatomy of 
natural biostructures such as rice husks, wood tissue, wood fibers and papers has attracted much interest ${ }^{(22-26)}$.

Cellular materials offer unique properties ${ }^{(27)}$ such as: good specific stuffiness and strength and high energy absorption under impact. Open cell materials can be useful in applications requiring interconnected porosity (filters, heat exchangers, etc.).

Biomorphic $\mathrm{SiC}$ is manufactured by a two step process: a controlled pyrolysis of the natural biostructure followed by a rapid controlled reactive infiltration of the carbon preform with molten $\mathrm{Si}$. The result is a $\mathrm{Si} / \mathrm{SiC}$ composite that replicates the interconnected microstructure of the biostructure ${ }^{(28)}$.

The present study deals with the synthesis of porous WC and SiC ceramic from novel biogenic source. Sugar cane has been chosen as carbon precursor material. The crystalline nature of the produced bodies, as well as their catalytic activity will be investigated.

\section{2 materials and methods:}

\subsection{Fabrication of the specimens}

The materials used were Egyptian sugar cane as a carbon precursor, chemically pure tungstic acid $\left(\mathrm{H}_{4} \mathrm{WO}_{2}\right.$, Fluka) as a source of tungsten element and Si powder ( Elken $\mathrm{HQ}$ from 1-10 $\mu \mathrm{m})$, as a source of Si. Cylindrical specimens with dimensions of $20 \mathrm{~mm}$ height and $20 \mathrm{~mm}$ diameter of the sugar cane were shaped and dried in air at 40 to $50^{\circ} \mathrm{C}$ till complete dryness. They were pyrolyzed at $800^{\circ} \mathrm{C}$ for $1 \mathrm{~h}$ in flowing $\mathrm{N}_{2}$ atmosphere under ambient pressure in an alumina tube furnace. A slow heating rate of $1^{\circ} \mathrm{C} / \mathrm{min}$ was applied up to $350^{\circ} \mathrm{C}$ with a soaking time of $2 \mathrm{~h}$ at the pyrolysis temperature, where the cellulose bonds were completely decomposed into carbon.

WC bodies were prepared by impregnating the pyrolysed sugar cane specimens in tungstic acid sol prepared by suspending $10 \mathrm{wt}$. \% of tungstic acid in $100 \mathrm{ml}$ deionized water, followed by a dropwise addition of about $10 \mathrm{ml}$ ammonia solution to ensure the complete dissolution of tungstic acid into ammonium para tungstate. The pyrolysed sugar cane samples were infiltrated with ammonium para tungstate solution under vacuum for $2 \mathrm{hrs}$, the samples were dried overnight at $90^{\circ} \mathrm{C}$. The dried samples were heated up to $1450^{\circ} \mathrm{C}$ for $4 \mathrm{hrs}$ under $\mathrm{Ar}$ atmosphere with a heating rate of $5^{\circ} \mathrm{C} / \mathrm{min}$.

To prepare Si/SiC composite the pyrolyzed sugar cane carbon specimens were mounted in a graphite crucible with the addition of $8 \mathrm{wt}$. \% of silicon under vacuum for $1 \mathrm{~h}$ to ensure complete formation of $\mathrm{SiC}$. Heat treatment at $1450^{\circ} \mathrm{C}$ with a soaking time of $1 \mathrm{~h}$ at the peak temperature in a graphite reactor under vacuum resulted in the formation of a porous $\mathrm{Si} / \mathrm{SiC}$ composite.

\subsection{Characterization}

The pyrolysis behavior of the investigate WC samples were characterized using differential thermal analysis(DTA) and thermogravimetric analysis (TGA) in $N_{2}$ atmosphere and alumina as a reference material with a heating rate of $10^{\circ} \mathrm{C} / \mathrm{min}$. (Netzsch, Bayern, Germany).

The microstructure of the final products was examined by scanning electron microscopy ( SEM Model XL 30, Philips, Eindhoven, Netherlands). XRD analysis using monochromated $\mathrm{Cu} \mathrm{K}_{\alpha}$ radiation (D 500, Siemens, Mannheim, Germany) was applied to identify crystalline reaction products. Apparent porosity of the fired specimens was 
evaluated using the Archimedes method (ASTM C-20).

The catalytic activity was measured for $1 \mathrm{ml}$ of the prepared solid using a flow technique (13) under normal pressure. The solid samples precalcined in stream of dry air $\mathrm{CO}_{2}$ free for $3 \mathrm{~h}$. After calcination the temperature was lowered to the reaction temperature which ranged between 200 and $450^{\circ} \mathrm{C}$. The reactant (cyclohexane or cyclohexene) was introduced by a Unipan 335A micro dose pump keeping the speed of feeding at $5.2 \times 10^{-}$ ${ }^{1} \mathrm{~min}^{-1}$.

The gaseous and liquid products were analyzed by gas - liquid chromatography (Perkin Elmer 8600) with flame ionization detector on column 5\% CW1540 on CSORB (GAWDMCS) using nitrogen as a carrier gas. The apparent activation energy and the specific activity were calculated from the conversion percentage of cyclohexane and cyclohexene.

\section{3-Results and Discussion}

\subsection{Biocarbon Preform Micros}

Figure (1, a\&b) gives the respective microstructural views of tangential-radial (TR) and axial-radial (AR) sections of biocarbon preform. They show characteristic arrangement of carbon web along with interconnected void structure.

The microstructure shows hollow channels of various diameters that originate from tracheid cells that are parallel to the axis of the plant. The channels can be clarified into three groups, depending on their cross-sectional area: rounded channels, elliptical shape channels and small channels, which form honey comb structures, Fig. (2). the average diameter of each group of cells are measured from the micrographs and found to be 80 $\mu \mathrm{m}$ for the round cells, $\sim 12 \times 45 \mu \mathrm{m}$ for the elliptical cells and $\sim 9 \mu \mathrm{m}$ for the small cells, Fig. (3).

\subsection{Si/SiC composite}

\section{2. 1. Phase composition}

The XRD - scan from a Si infiltrated pyrolysed sugar cane sample is shown in Fig. (4). $\beta$ $\mathrm{SiC}$ and $\mathrm{Si}$ are the only crystalline phases present.

\section{2. Microstructure of the Si/SiC composite:}

The SEM micrographs of the resulting porous $\mathrm{Si} / \mathrm{SiC}$ composite are shown in Fig. (5, A \& B). As may be seen, the initial cellular anatomy was retained in the ceramic product. Some needle-like SiC whiskers of nanometric diameter can be observed in the cellular pores, Fig. (6). According to Lee (29) and Paccaud and Derre (30) half of the initial carbon is supposed to be released from the template via $\mathrm{CO}(\mathrm{g})$ evaporation. From SEM observations it is concluded that the highly porous cell wall material between the cells formed in the intial state of reaction led to the rapid transport of the gas through SiC layer. Accordingly, tailoring of the strut microstructure by suitable processing techniques seems to play a key role for improving the mechanical properties of the produced bodies. These conclusions are in an agreement with the findings of Qian et al (31). 


\subsection{WC Porous Bodies}

\section{3. 1. DTA and TGA analysis}

Figure (7) showed that during heat process the trapped gases absorbed water, volatiles and surface oxides present in the bicarbon preform and ammonium para tungstate gel were released in the temperature range of $400-800^{\circ} \mathrm{C}$.

Significant weight loss results were obtained only at temperatures above $875-1000^{\circ} \mathrm{C}$. It may be due to the break down of ammonium salt and the formation of transient metallic $\mathrm{W}$. The two exothermic peaks observed at the temperature range of $925-1000^{\circ} \mathrm{C}$ is due to the formation of $\mathrm{W}_{2} \mathrm{C}$ and $\mathrm{WC}$ phases. At temperatures above $1000^{\circ} \mathrm{C}$ up to $1400^{\circ} \mathrm{C}$, weight loss is still in progress indicating that the reaction to produce WC is still going on. However, at $1450^{\circ} \mathrm{C}, W C$ is the only phase exists as indicated by XRD analysis, Fig. (8). The sequence of formation of tungsten carbide is in agreement with the published literature ${ }^{(32)}$, even if the carburization procedure is different.

\section{3. 2. Phase composition}

The XRD pattern of the produced bodies fired at $1450^{\circ} \mathrm{C}$ for $4 \mathrm{hrs}$ is shown in Fig. (8). It indicates that WC (JCPDS: $25-1047$ ) is the single phase obtained. WC displays five crystal planes, (100), (101), (001), (111) and (102); this implies that the crystallinity of WC is well enough ${ }^{(33)}$.

\section{3. 3. Microstructure of the synthesized WC bodies}

The SEM micrographs of the porous WC bodies shown in Fig. (9, A \& B) indicates that the resulting WC material is of a pseudomorphous microstructure similar to the biocarbon template they are derived from. The cell wall material between the cells is a dense strut material, which prevent the structure from being destroyed and keep the structural integrity of the product, Fig. (10). WC particles exhibit two different crystalline shapes, rounded WC grains, which is not likely to form via solution reprecipitation process during sintering due to energy reasons (i.e. formation of low energy crystal interfaces) ${ }^{(34)}$, and lath like grains. The surface of such "rounded" grains are strongly micro-facetted and multi-stepped. The steps consist of low-energy planes, which form during the sintering process. The grains have no sharp edges and, therefore, are considered to be "rounded". The nano-sized rounded grains are agglomerated in clusters Fig. (11) while, the lath-like grains show abnormal grain growth. The origin of the abnormal grain growth is not clearly understood. It may be; similar to the $\mathrm{Al}_{2} \mathrm{O}_{3}$ grain growth; due to a singular grain boundary. Park and Yoon ${ }^{(35)}$ stated that singular grain boundary requires special growth mechanisms for grain growth, such as 2-D nucleation and screw dislocations.

They showed that if the driving force for grain growth is sufficiently large, the 2-D nucleation process cannot restrict its growth. However, if the driving force is small, the grain growth will be affected by the rate of 2-D nucleation on the singular surface. In this case, even a small amount of singular boundary among the total grain boundaries could inhibit the total grain growth by pinning the grain boundary movement at the triple point.

In the case of WC, the grain boundary is regarded as singular. Therefore, there exists sufficient possibility to result in abnormal grain growth. Fig. (12, A \& B) shows an interesting nano-fibrillar WC formed inside the WC channels. We believe that they results from the decomposition of carbohydrates inside the chambers. The formation mechanism of such nano- fibrillar WC is not clear and need to be studied. Figure (12, C) shows EDS 
scan image of the fibrillar WC.

\subsubsection{Catalytic properties}

The catalytic activity measurements were followed using cyclohexane at different temperatures ranged between 200 and $450^{\circ} \mathrm{C}$. Analyses of reaction products by gas-liquid chromatograph emphasized the presence of cyclohexene as a lone product at temperature range $200-350^{\circ} \mathrm{C}$ and at $400,450^{\circ} \mathrm{C}$ benzene produced with 4.95 and $28.09 \%$ respectively. Fig. 13 a. shows the variation of conversion \% with temperature. It is evidence that the rate of dehydrogenation increases by temperature.

The apparent activation energy $[\Delta \mathrm{E}]$ for cyclohexane conversion over the investigated catalyst was calculated at the selected temperatures $200-450{ }^{\circ} \mathrm{C}$ using Arrhenius equation. Fig.14. represents linear plot of Arrhenius relation with temperature. The value of $[\Delta \mathrm{E}]$ was found to be $10.37 \mathrm{~kJ} / \mathrm{mole}$, indicating the high reactivity for cyclohexane conversion over the investigated catalyst. It follows from the analysis of liquid products that cyclohexene and benzene formed depending on the reaction conditions. Moreover, methane was formed during the decomposition of cyclohexane(13) according to the following equations

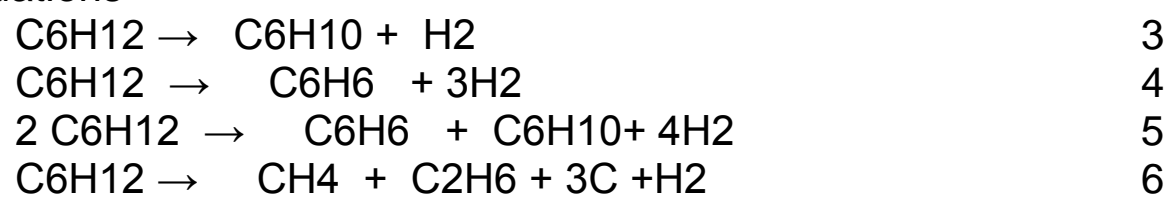

It is evident from the obtained results in Table 1 that, cyclohexane undergoes partial dehydrogenation to produce cyclohexene at lower temperature and by rising the temperature benzene formed together with cyclohexene so the reaction may proceed by step 1 at temperatures $200-350^{\circ} \mathrm{C}$ and by step 2 or 3 at 400 and $450^{\circ} \mathrm{C}$.

It is of interest to study the disproportionation process of cyclohexene over the catalyst under investigation. The catalytic conversion of cyclohexene over the investigated catalyst was studied at the same temperature range; it was found that the rate of dehydrogenation of cyclohexene increases by temperature as indicated in Fig. $13 \mathrm{~b}$. The analysis of liquid products by gas-liquid chromatography indicates the presence of benzene and cyclohexane and unreacted cyclohexene. The reaction was more selective for cyclohexane formation at temperatures $200-350^{\circ} \mathrm{C}$, and at temperature 400 and $450^{\circ} \mathrm{Cthe}$ reaction be more selective for benzene formation as indicated in Table 1 . The analysis of the liquid products indicates the formation of cyclohexane, benzene and traces of cyclohexadiene, so the mechanism $(13,14)$ may be;

$\begin{array}{ll}\mathrm{C} 6 \mathrm{H} 10 \rightarrow \mathrm{C} 6 \mathrm{H} 8+\mathrm{H} 2 & 7 \\ \mathrm{C} 6 \mathrm{H} 10 \rightarrow \mathrm{C} 6 \mathrm{H} 6+2 \mathrm{H} 2 & 8 \\ 2 \mathrm{C} 6 \mathrm{H} 10 \rightarrow \mathrm{C} 6 \mathrm{H} 6+\mathrm{C} 6 \mathrm{H} 12+\mathrm{H} 2 & 9 \\ 3 \mathrm{C} 6 \mathrm{H} 10 \rightarrow \mathrm{C} 6 \mathrm{H} 6+2 \mathrm{C} 6 \mathrm{H} 12 & 10\end{array}$

It can be concluded from analysis of liquid products and data given in Table 1. that cyclohexane and benzene are not in the same ratio, so the disproportionation process is not the only possible but the all other mentioned processes may take place. 


\section{Conclusion}

1. Highly porous $\mathrm{Si} / \mathrm{SiC}$ and WC ceramic with a sugar-cane microstructure were prepared at $1450 \mathrm{oC}$ in an argon atmosphere by the reaction of $\mathrm{Si}$ and tungstic acid with sugar-cane biocarbon preforms.

2. The resulting $\mathrm{Si} / \mathrm{SiC}$ ceramic is composed of $\beta-\mathrm{SiC}$ and $\mathrm{Si}$, while WC ceramic is composed of WC phase only.

3. The Si/SiC composite showed three groups of channels: rounded, elliptical shape and small channels, which form honey comb structures. The average diameter of each group of cells is measured from the micrographs and found to be $80 \mu \mathrm{m}$ for the round cells, $\sim 12 \times 45 \mu \mathrm{m}$ for the ellipse cells and $\sim 9 \mu \mathrm{m}$ for the small cells, filled with different lengths of $\mathrm{SiC}$ whiskers.

4. The resulting WC samples are composed of rounded and lath like crystals as well as nano-fibrillar WC.

5. Conversion of biogenic materials into ceramics with a microstructure pseudomorphous to the biogenic template anatomy offers a great potential for designing novel ceramics with anisotropic cellular morphologies.

6. The prepared catalyst exhibit higher activity for dehydrogenation of cyclohexane to cyclohexene with selectivity reaches to $96 \%$ at temperature $200-350^{\circ} \mathrm{C}$ while at 400 and $450^{\circ} \mathrm{C}$ the selectivity for benzene formation increases. Studying of cyclohexene conversion emphasized catalytic activity of the prepared catalyst and the reaction is selective for disproportionation, but also dehydrogenation may take place.

\section{References:}

[1] Beardsley T., "Fine grains". Scientific America, 10 (1992) 114-115.

[2] Leclercq I., Provost M., Grimblot H., Hardy A.M. and Gengembre L., "Catalytic properties of transition metal carbides".J.Catalysis, 117 (1989) 371-83.

[3] Ledoux M. J., Pham C. H., Guille J. and Dunlop H., "Compared activities of platinum and high surface area Mo2 and WC catalysts for reforming reactions". J.Catalysis, 134 (1992) 383-98.

[4] Koc R., Kodambaka S.K., "Tungsten carbide (WC) synthesis from novel precursors". J.Eur.Ceram.Soc., 20 (2000) 189-69.

[5] Upadhayaya G.S., "Sintered metallic and ceramic materials". New York; Wiley, 2000.

[6] Exner H.E., "Physicl and chemical nature of cemented carbides". Int.Met.Rev., 4 (1979) 149-73.

[7] Klaer P., Kiefer F., Stjemberg K. and Oakes J.J., "The influence of binder constitution on the shape of WC grains". Adv.Powder Mettal. Part.Mater., 3 [10] (1999) 51-61.

[8] Herber R-P., Schubert W-D. and Lux B., "Hardmaterials with "rounded" WC grains". Ref.Met.Hard Mater., 24 (2006) 360-64.

[9] Oyama S.T., Yu C.C. and Ramanathan J., "Transition metal bimetallic oxycarbides: synthesis, characterization and activity study". J.Catal.184 (1999)535.

[10] Oyama S.T., "The Chemistry of Transition Metal Carbides and Nitrides", Blackie Academic and Professional Glasgow, 1996.

[11] Oyama S.T., "Preparation and catalytic properties of transition metal carbides and nitrides". Catal. Today 15 (1992) 179.

[12] Chen J. G., "Conversion of hydrocarbons over cobalt oxide". Chem. Rev. 96, (1996)1477.

[13] Ezzo E.M., Yousef N. A. and Ali S.A., "Conversion of hydrocarbons over an Ni- 
Al2O3 catalyst I: Surface and catalytic studies of the Ni-Al2O3 catalyst". Surf. Technol.,13 (1981) 379

[14] ibid, idem, "Conversion of hydrocarbons over an Ni-Al2O3 catalyst II: Study of the mechanism of conversion of cyclohexene". 14 (1981) 177

[15] Gao L. and Kear B.H., "Low temperature carburization of high surface area tungsten powders". Nanstruct.Mater., 5 (1995) 555-69.

[16] Gao L. and Kear B.H., "Synthesis of nanophase WC powder by a displacement reaction process". Nanostruct.Mater., 9(1997) 205-08.

[17] Medeiros F.F., De Oliveira S.A., De Souza C.P., Da Silva A.G.P., Gomes U.U. and De Souza J.F., "Synthesis of tungsten carbide through gas-solid reaction at low temperature". Mater.Sci.Engin.A., 315 [1-2] (2001) 58-62.

[18] Giraudon J.M., Devassine P., Lamonier J.F., Delannoy L., Leclereq L. and Leclereq G., "Synthesis of tungsten carbide by temperature-programmed reaction with $\mathrm{CH} 4$ $\mathrm{H} 2$ mixtures. Influence of the $\mathrm{CH} 4$ and hydrogen content in the carburization mixture". J.Solid State Chem., 154 [2] (2000) 412-26.

[19] Akiohara M.M. and Ayano N., "Process for the production of tungsten carbide or mixed metal carbides". US Patent No: 4(1977), 008, 090,.

[20] Koc R. and Kodambaka S.K., "New process for production submicron tungsten monocarbide powders". J.Mater.Sci.Lett., 18 (1999) 1469-71.

[21] Swift G.A. and Koc R.," Formation of WC powders using carbon coated precursors". J.Mater.Sci., 35 [9] (2000) 2109-2113.

[22] Ding S., Zeng Y-P. and Jiang D. " In-Situ Reaction Bonding of Porous SiC Ceramics" Mater. Charac.., 59 (2008) 140-143.

[23] Mallick D., Chakrabarti O.P., Maiti H. S. and Majumdar R. "Si/SiC Ceramics from Wood of Indian Dicotyledonous Mang Tree" Ceram. Int. 33 (2007) 1217-1222.

[24] Kenawy S. H., Awaad M., Naga S., Windsheimer H. and Greil P. "Porous Si/SiC composite Based on Nonwoven Cellulosic Fabrics: Synthesis and Characterization" Int. J. Appl.Cerami. Technol., 5 (6) (2008) 618-623.

[25] Bhattacharya A. and Heinrich J. G. "cellular SiC Ceramic from Stem of CornProcessing and Microstructure" J. Mater. Sci. 41 (2006) 2443-2448.

[26] Presas M., Pastor J. Y., Lorca J. L., Arellano-Lopez A. R., Fernandez J. M- and Sepulveda R. E. "Mechanical Bhavior of Biomorphic Si/SiC Porous Composites" Scripta Mater., 53 (2005) 1175-1180.

[27] Sieber H., Hoffmann C., Kaindl A., and Greil P. "Biomorphic Cellular Ceramics" Adv. Eng. Mater., 2 (3) (2000) 105-109.

[28] Presas M., Pastor J. Y., Lorca J. L., Arellano-Lopez A. R., Fernandez J. M- and Sepulveda R. E. "Microstructure and Fracture Properties of Biomorphic SiC" Int. J. Ref. Met. Hard. Mater., 24 (2006) 49-54.

[29] Lee Y. J. "Formation of Silicon Carbide on Carbon Fibers by Carbothermal Reduction of Silica" Diamond and Related Mater., 13 (3) (2004) 383-388.

[30] Paccaud P. and Derre A "Silicon Carbide Coating by Reactive Pack CementationPart II: Silicon Monoxide/Carbon Reaction" Chem. Vapor., 6 (1) (2000) 41-50.

[31] Qian J., Wang J. and Jin Z. "Preparation of Biomorphic SiC Ceramic by Carbothermal Reduction of oak Wood Charcoal" Mater. SCi. Eng., A 371 (2004) 229-235.

[32] Lechercq G., Kamel M., Giraudon J. M., Devassine P. and Feigenbaum L. "Study of the Preparation of Bulk Powder Tungsten Carbides by Temperature Programmed Reaction with Ch4+H2 Mixtures" J. Catal., 158 (1996) 142-169.

[33] Li G., Anma C., Tang J. and Sheng J. "Preparation and Electro catalytic Property of W/C Carbon Nanotube Composite" Electrochim Acta 52 (2007) 2018-2023.

[34] Herber R. P., Schubert W. D. and Lux B. "Hard metals with Rounded WC Grains" 
Int. J. Refract. Met. Hard Mater. 24 (2006) 360-364.

[35] Park C. W. and Yoon D. Y. "Effect of $\mathrm{SiO} 2, \mathrm{CaO} 2$ and $\mathrm{MgO}$ Additions on the Grain Growth of Alumina" J. Am. Ceram. Soc., 83 (10) (2000) 2605.

Table 1.Variation of dehydrogenation products \%of cyclohexane and cyclohexene conversion with temperature

\begin{tabular}{|c|c|c|c|c|c|}
\hline \multirow{2}{*}{$\begin{array}{l}\text { Temp., } \\
{ }^{\circ} \mathrm{C}\end{array}$} & $\begin{array}{l}\text { Products of cyclohexane } \\
\text { conversion } \%\end{array}$ & \multirow[t]{2}{*}{$\mathrm{S}_{\mathrm{e}} \%$} & $\begin{array}{l}\text { Products of cyclohexene } \\
\text { conversion } \%\end{array}$ & \multirow{2}{*}{$\begin{array}{l}\mathrm{S}_{\mathrm{a}} \\
\%\end{array}$} & \multirow{2}{*}{$\begin{array}{l}\mathrm{S}_{\mathrm{b}} \\
\%\end{array}$} \\
\hline & $\begin{array}{l}\text { Cyclohexene } \\
\text { Benzene }\end{array}$ & & $\begin{array}{l}\text { Cyclohexane } \\
\text { Benzene }\end{array}$ & & \\
\hline 200 & $\begin{array}{c}22.88 \\
---\end{array}$ & 89.34 & $\begin{array}{l}3.96 \\
1.05\end{array}$ & 60.83 & 16.13 \\
\hline 250 & $\begin{array}{c}29.73 \\
---\end{array}$ & 80.24 & $\begin{array}{l}4.20 \\
1.75\end{array}$ & 70.47 & 29.36 \\
\hline 300 & $\begin{array}{l}43.06 \\
---\end{array}$ & 96.03 & $\begin{array}{l}7.07 \\
1.99\end{array}$ & 57.39 & 16.15 \\
\hline 350 & $\begin{array}{c}45.66 \\
---\end{array}$ & 96.49 & $\begin{array}{l}8.83 \\
3.00\end{array}$ & 58.98 & 20.04 \\
\hline 400 & $\begin{array}{c}47.83 \\
4.95\end{array}$ & 90.43 & $\begin{array}{c}6.82 \\
16.26\end{array}$ & 27.31 & 65.12 \\
\hline 450 & $\begin{array}{l}42.53 \\
28.09\end{array}$ & 59.36 & $\begin{array}{l}14.13 \\
15.57\end{array}$ & 39.26 & 26 \\
\hline
\end{tabular}

Se $=$ Selectivity for cyclohexene $\%=\frac{\text { cyclohexene } \%}{\text { Total conversion }} \times 100$

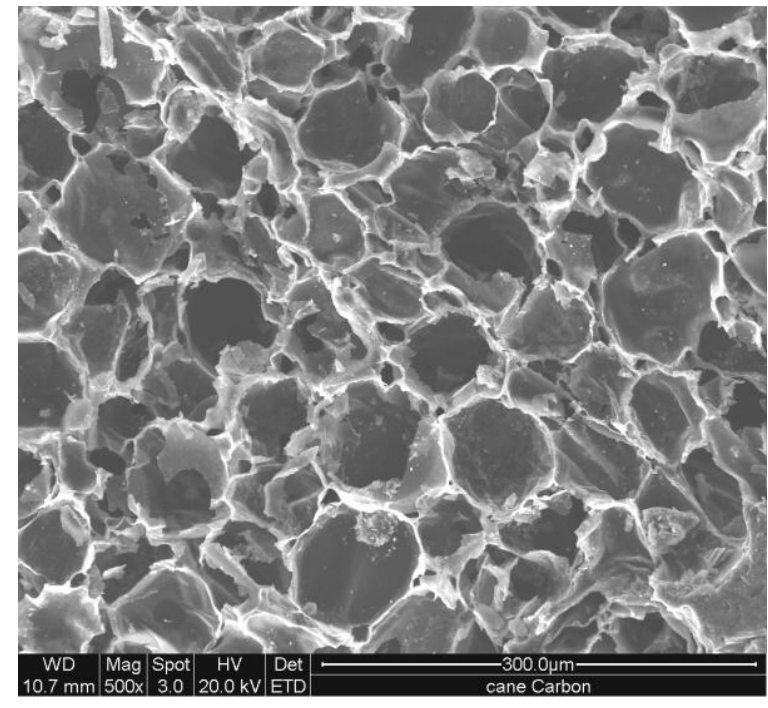

(A)

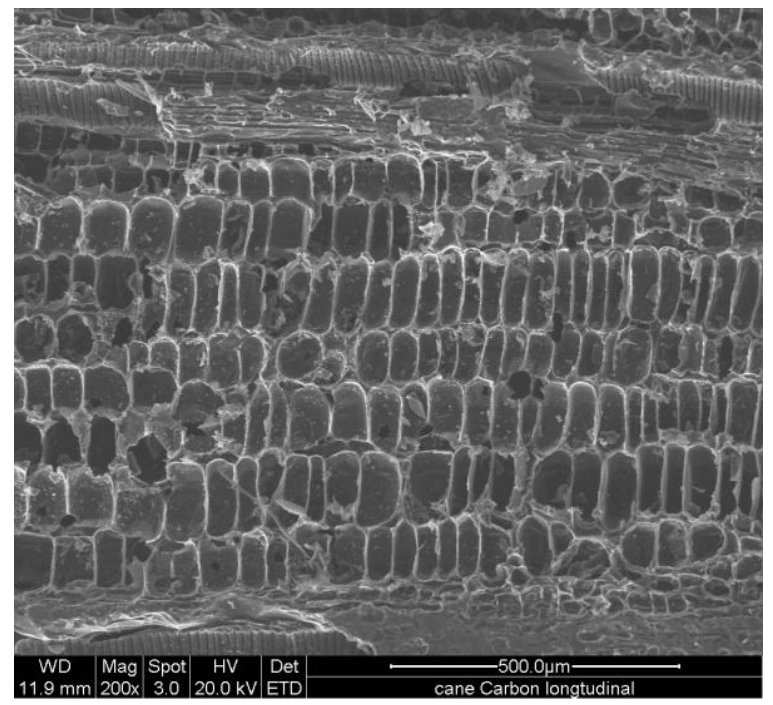

(B)

Fig. (1) SEM Images of the Pyrolysed sugar cane under Ar atmosphere up to $800^{\circ} \mathrm{C}(\mathrm{A})$ tangential-radial (TR) (B) Axial-radial (AR) Section 


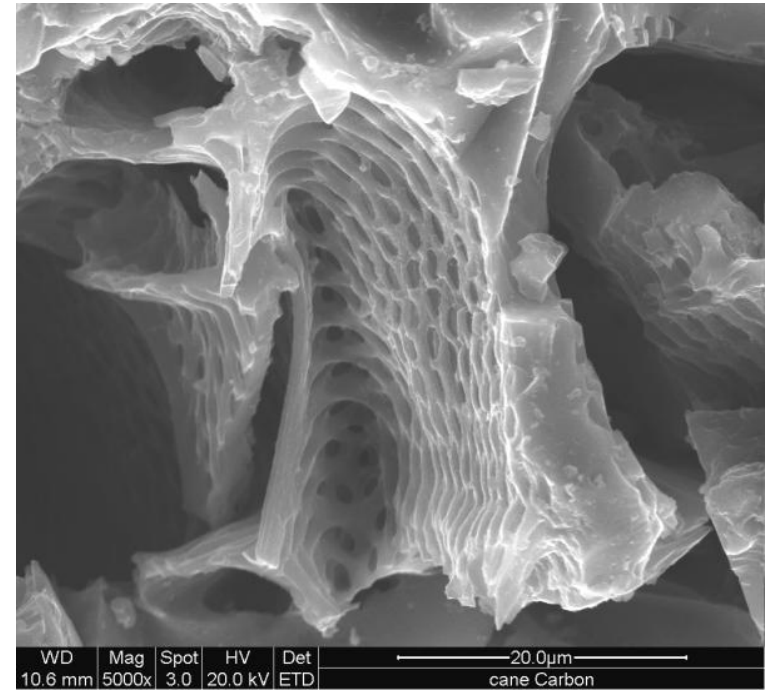

(A)

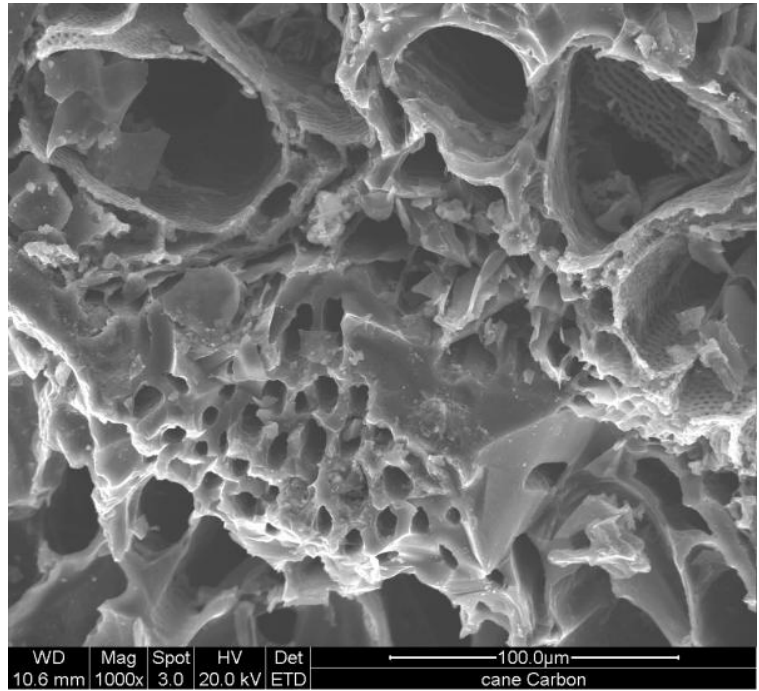

(B)

Fig. (2) SEM Images of the Small (Honey Comb) Cell Structure and porous cell wall

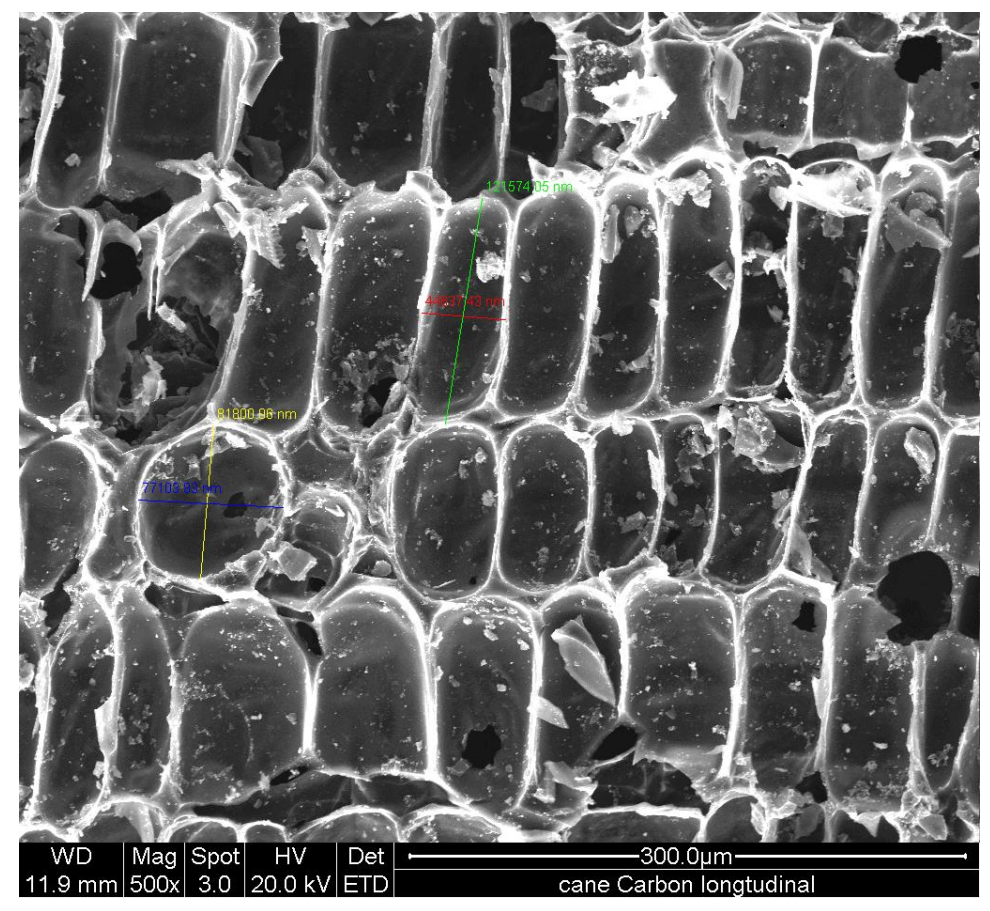

Fig. (3) SEM Micrograph Showing the Diameter of Rounded and Elliptical Channels of the Biocarbon Sugar Cane Preform 


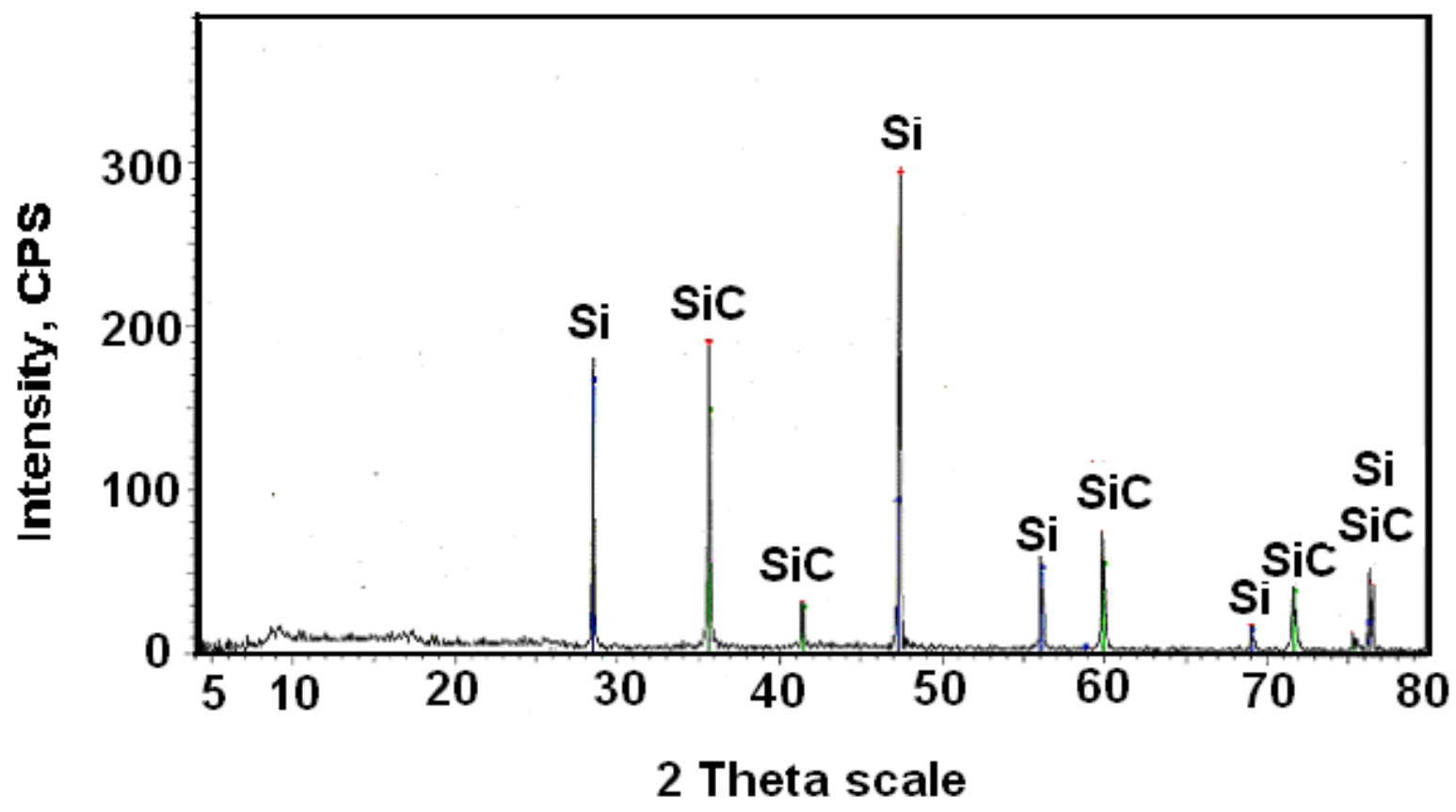

Fig. (4) XRD profiles of Si- infiltrated carbonaceous preform from sugar cane showing the presence of $\mathrm{Si}$ and $\beta-\mathrm{SiC}$

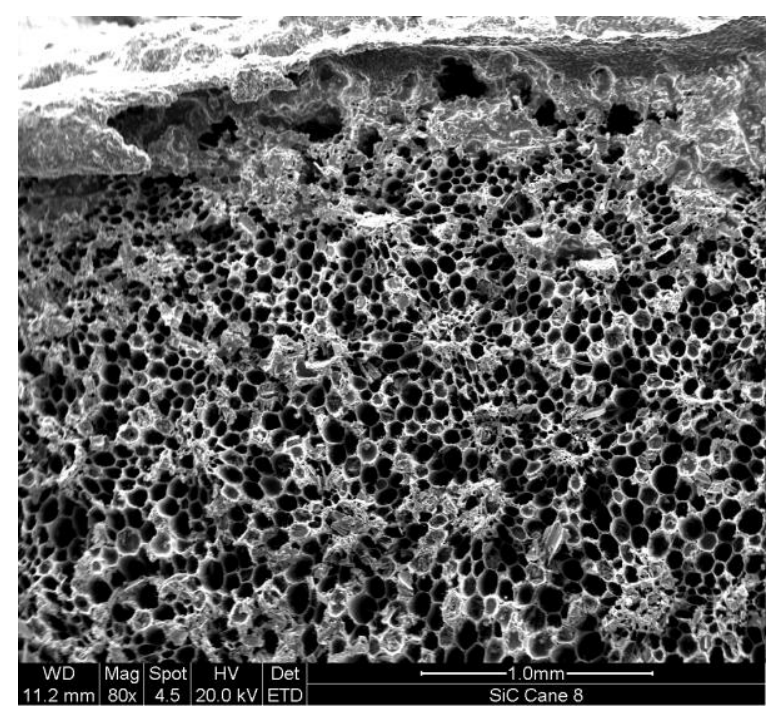

(A)

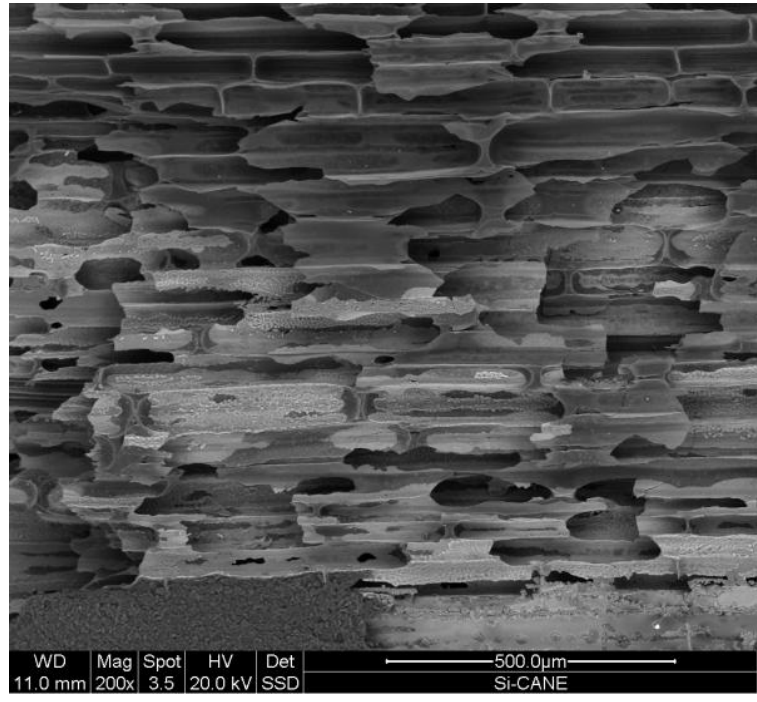

(B)

Fig. (5) SEM images of the SiC prepared from Sugar Can and 8 wt.\% Si slurry 


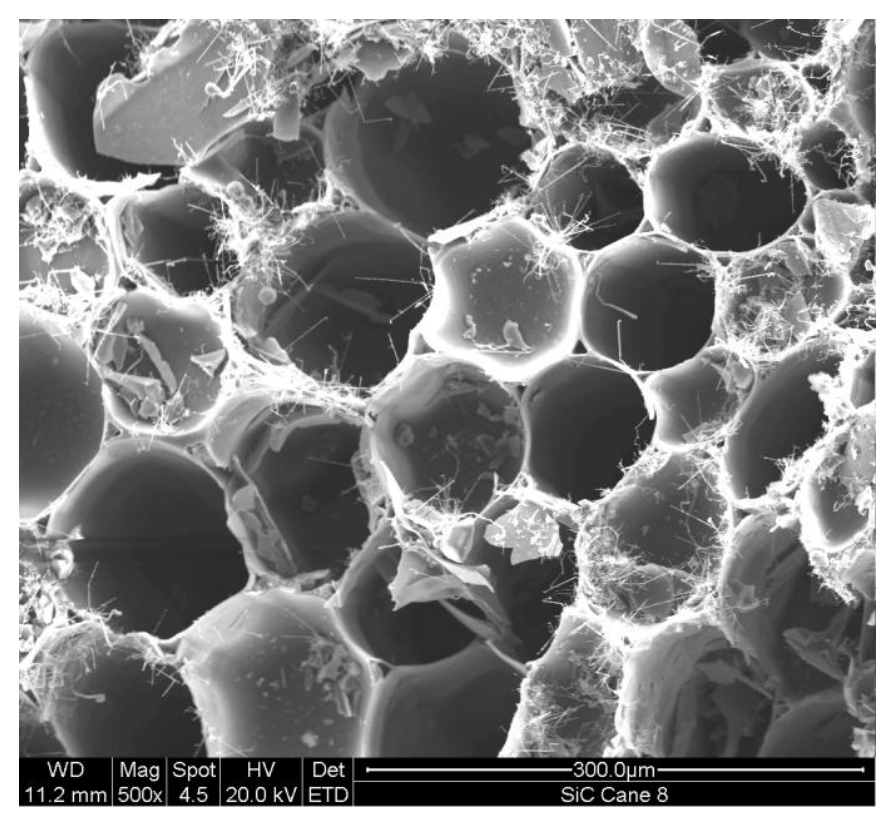

Fig. (6) SEM Image of the needle-like SiC whiskers in the cellular pores

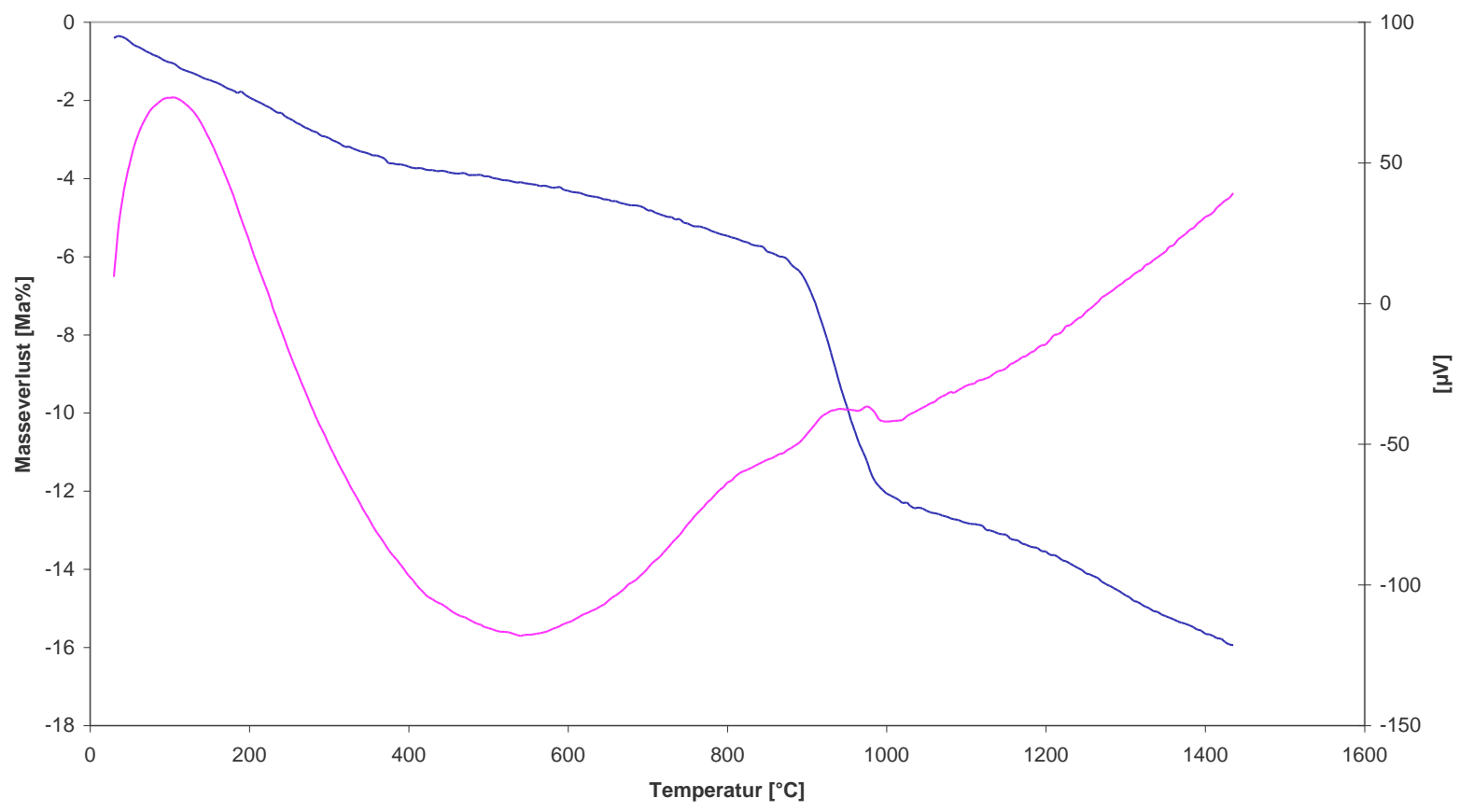

Fig. (7) DTA and TGA of the Tungestic acid- infiltrated carbonaceous perform from sugar cane 


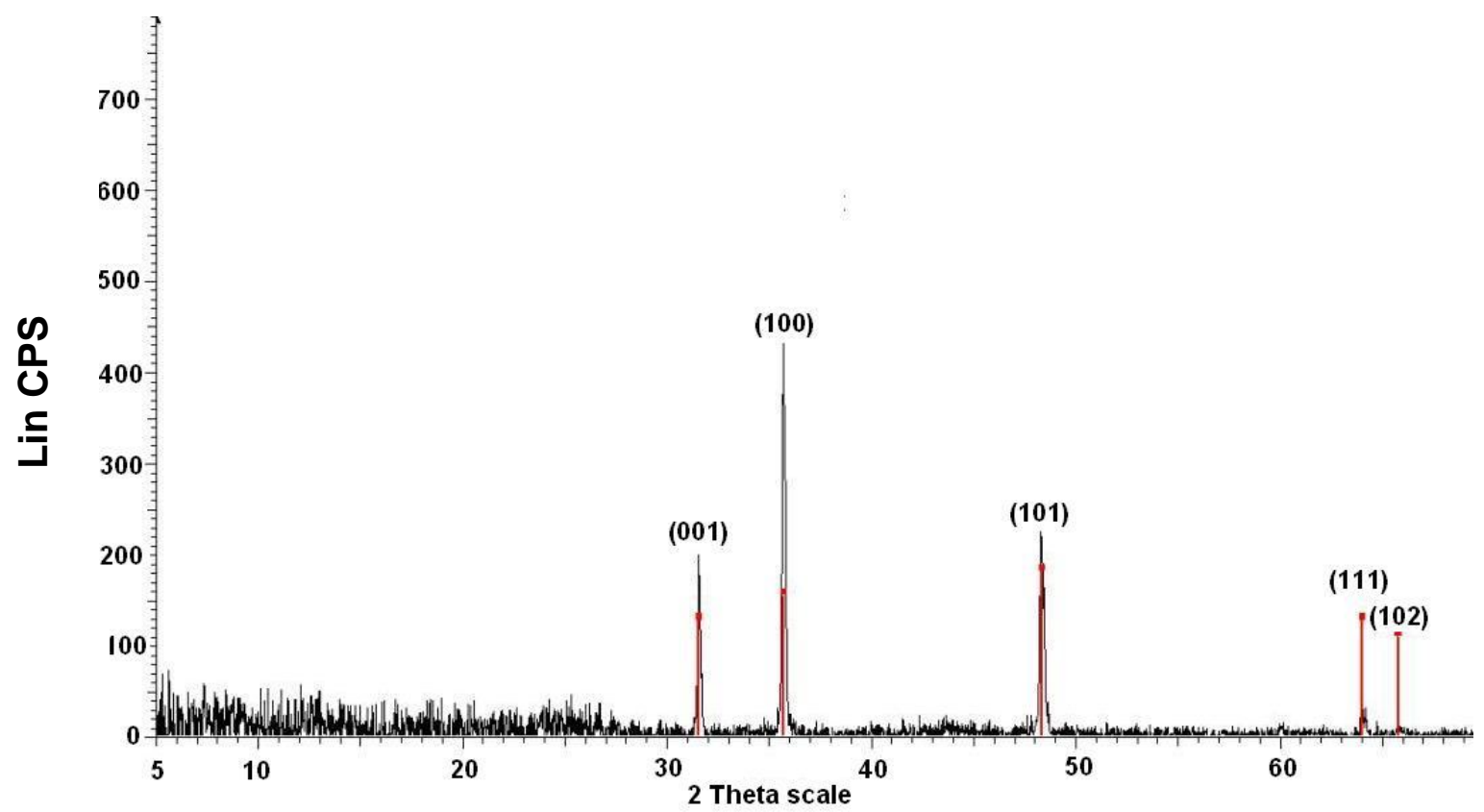

Fig. (8) XRD of the Synthesized WC from Sugar Can precursor after heat treatment up to $1450^{\circ} \mathrm{C}$

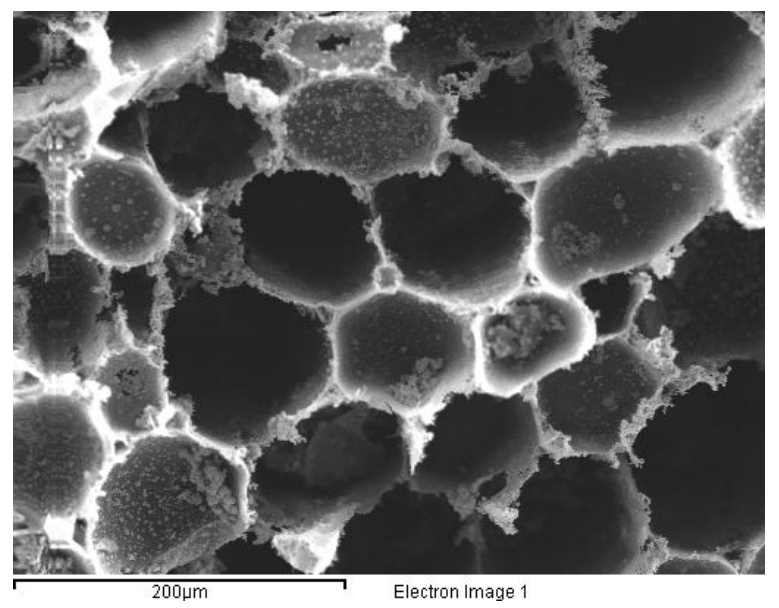

(A)

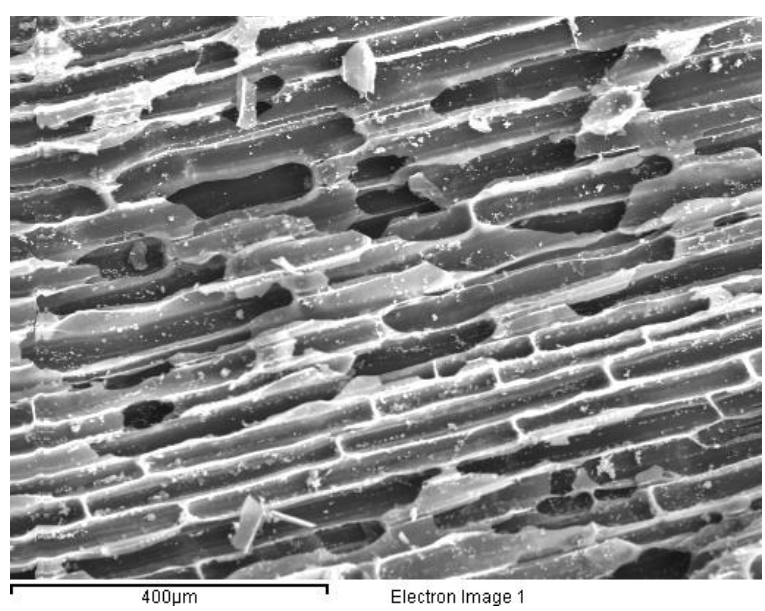

(B)

Fig. (9) SEM of Wolfram Carbide (WC) Prepared from Sugar Cane and 10 wt.\% Tungstic Acid Dissolved in Ammonia Solution

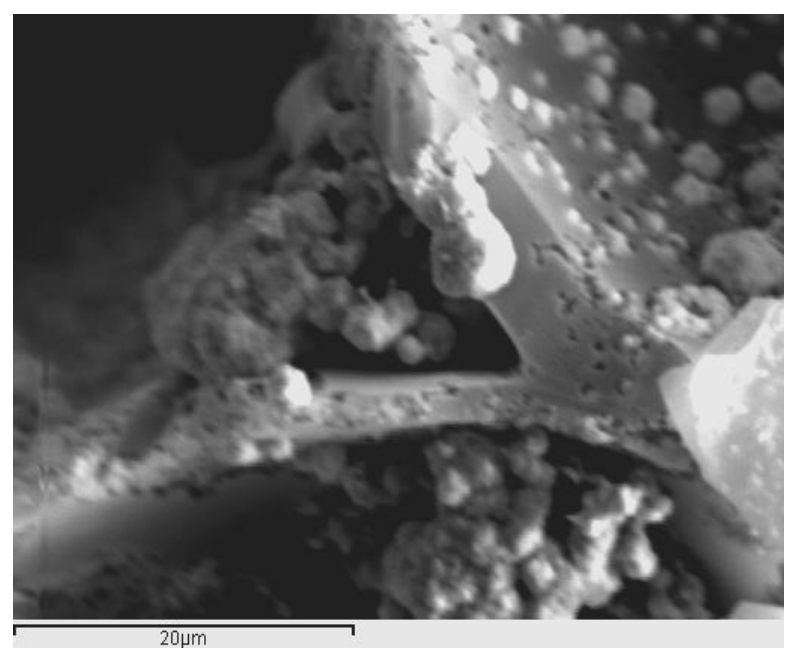

Fig. (10) SEM micrograph of the dense strut wall material 

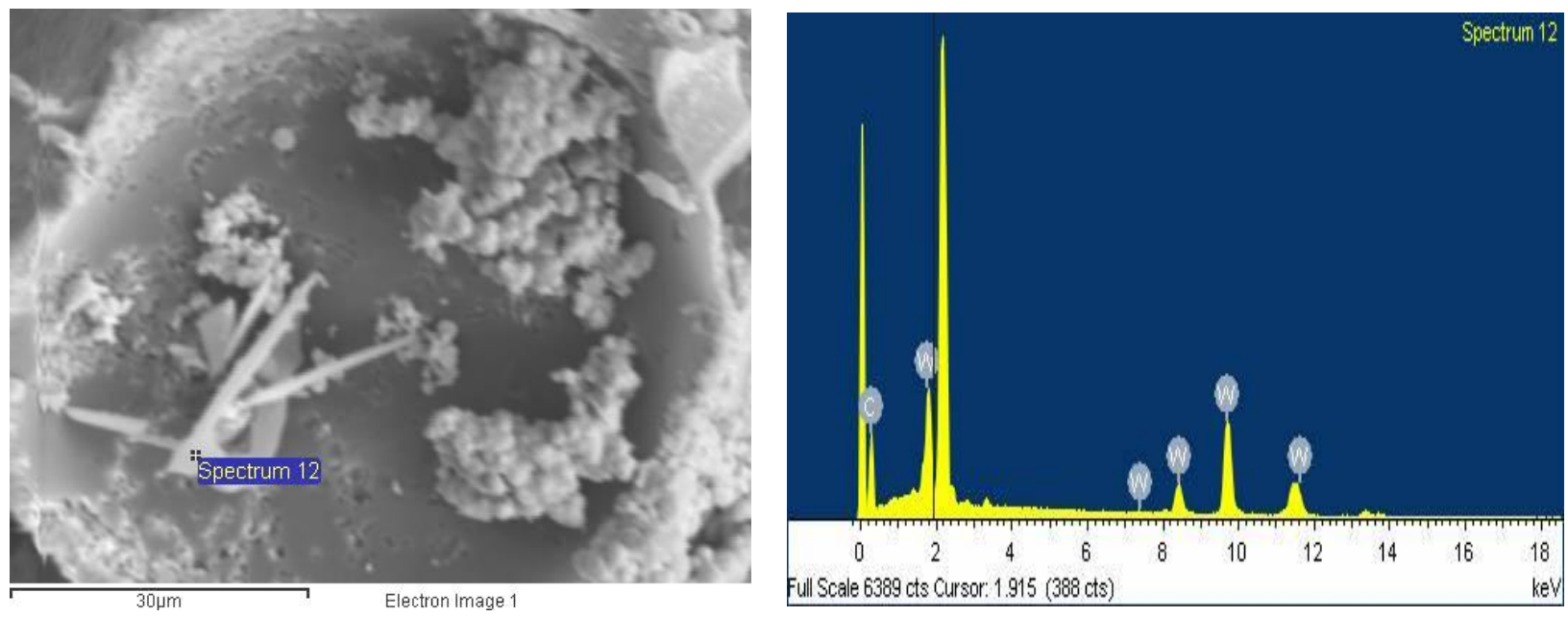

Fig. (11) SEM image of WC body with rounded and lath-like particles with EDX analysis
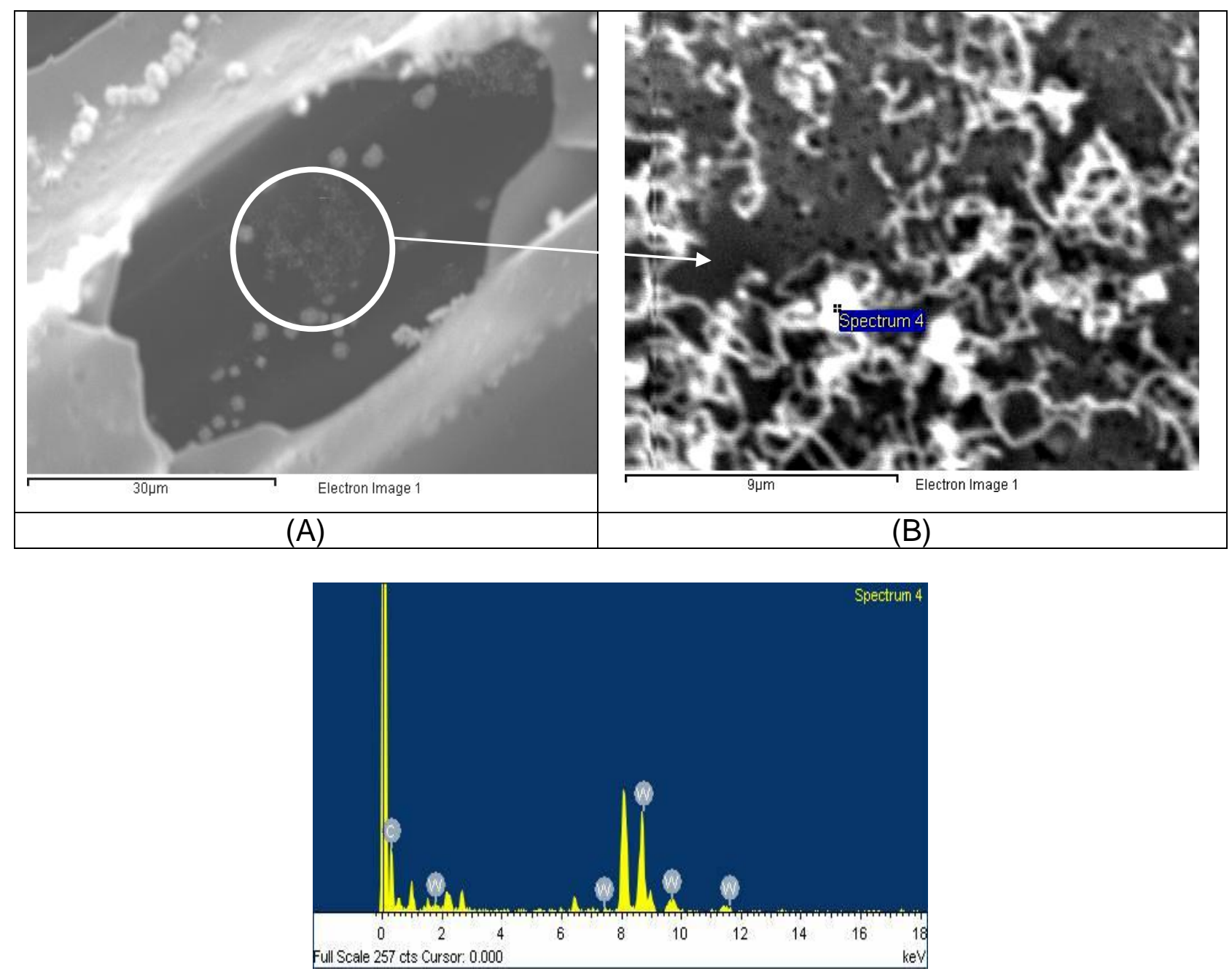

Fig. (12, A \& B and C) SEM and EDX images of the Nano-particles and nano-fibrillar of WC sample 


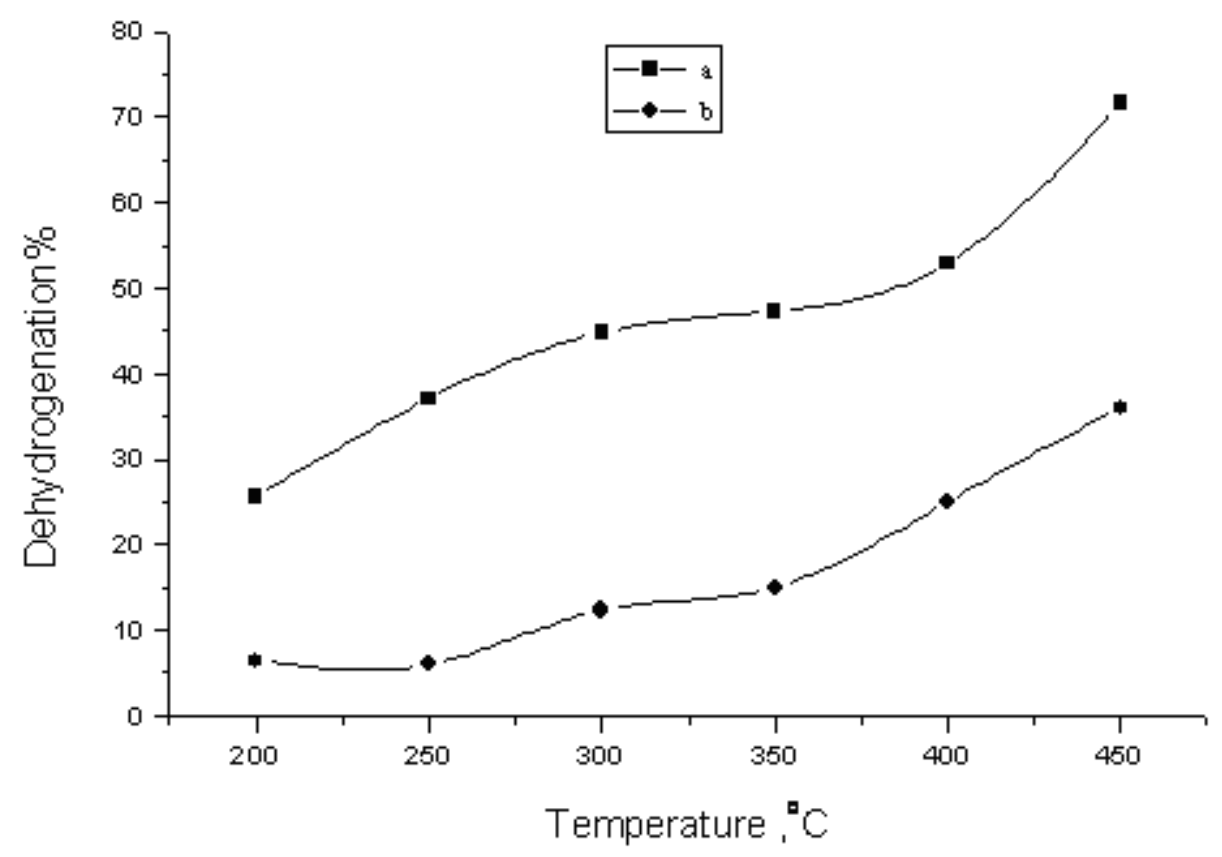

Fig.13.Effect of temperature on dehydrogenation \% of: (a) cyclohexane and (b) cyclohexene

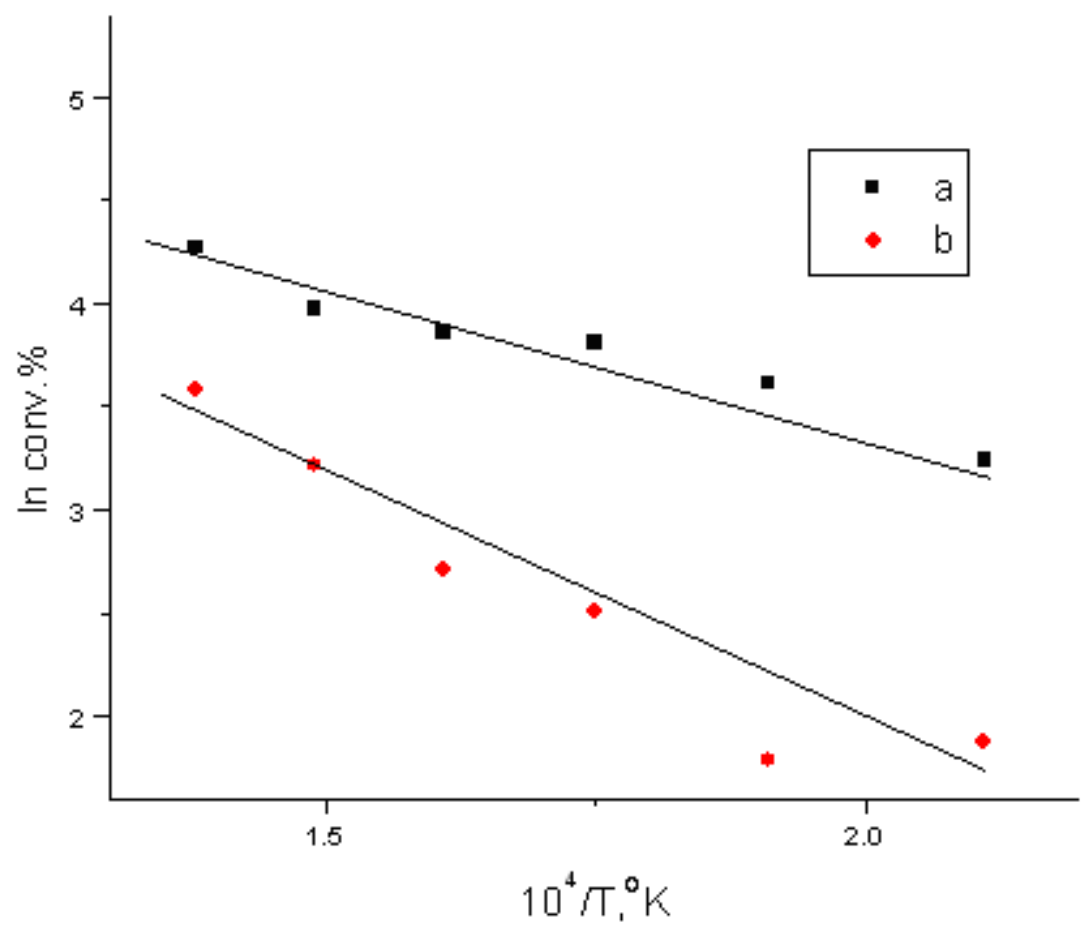

Fig.14. Arrhenius plot for conversion $\%$ of cyclohexane and cyclohexene reactant, $a=$ for cyclohexane, $b=$ for cyclohexene 